\title{
Terrorism and Country-Level Global Business Failure
}

\section{Abstract}

\author{
Ishmael Tingbani ${ }^{{ }^{*}}$ \\ itingbani@bournemouth.ac.uk \\ Godwin Okafor ${ }^{2}$ \\ godwin.okafor@dmu.ac.uk \\ Ven Tauringana ${ }^{3}$ \\ V.Tauringana@soton.ac.uk \\ Alaa Mansour Zalata ${ }^{3,4}$ \\ a.zalata@soton.ac.uk
}

This paper contributes to the literature on business failure by investigating the relationship between terrorism and country-level global business failure by using a sample of 174 countries over the period 2009-2015. To proxy for business failure, the 'Resolving Insolvency' index, which is a component of the World Bank's 'Doing Business' index, was adapted and used. The results of the fixed-effects estimation show that terrorism has a positive and significant relationship with business failure for the full sample. When the sample is divided into developed, developing and fragile states, the results show that terrorism is positively and significantly related with business failure in developing and fragile states only. Estimates show that for every 100 terrorist incidents, business failure increases by 1\% and 0.7\% points, in South Asia and Sub Saharan Africa (SSA) countries, respectively. The findings contribute to our understanding of the effects of terrorism on business failure, and how this differs depending on whether the country is developing, developed, or is a fragile state.

Key words: Terrorism, Country-Level, Global Business Failure and Fragile States JEL Classification: G14, G21 and G22

\footnotetext{
${ }^{1}$ Bournemouth Business School, Bournemouth University, 89 Holdernhurst Road, Bournemouth BH8 8EB, UK. * Corresponding Author .

${ }^{2}$ Faculty of Business and Law, Leicester Castle Business School. De Montfort University, The Gateway, Leicester, LE1 $9 \mathrm{BH}$.

${ }^{3}$ Southampton Business School, University of Southampton, Highfield, Southampton, SO17 1BJ, UK.

${ }^{4}$ Faculty of Commerce, Mansoura University, Mansoura, Egypt.
} 


\section{Introduction}

Terrorism is a new global business threat that has become a major challenge to the conduct and survival of global business (Jain \& Grosse 2009). Terrorism assumes many forms making it very difficult to predict its occurrence and impact (Enderwick 2006; Shrivastava 2005). Its impact on global business has been the focus of several recent theoretical and empirical research papers (Abadie \& Gardeazabal 2008; Bader \& Berg 2013; Enderwick 2001; Jain \& Grosse 2009). Collectively, the evidence from these studies suggests, that beyond the loss of life, personal injuries and fear that the terrorists seek to create, terrorism has real multiple economic consequences, which are detrimental to the survival of international businesses (Kollias et al. 2011). This paper investigates the impact of terrorism on country-level global business failure, and also determines whether there are differences in its effects on business failure in developed, developing, and fragile countries.

Our motivation, which is to focus on the effect of terrorism on global business failure, is rooted in normative disagreements regarding the impact of terrorism on global businesses, and on a dearth of empirical evidence on whether terrorism causes business failure around the world. The major normative argument for expecting terrorism to lead to business failure is that it will increase costs for the businesses that cannot be met from the revenue stream. For example, some of the research have suggested that following a terrorist attack, and where there is a need for structural repairs (Enderwick 2001; Ghemawat 2003; Suder 2004), that employees will be unwilling to work during the night or at the weekends, thereby, increasing the costs for business (Brodeur 2017; Enderwick 2001). Also, it has been suggested that safety concerns in terrorism-affected countries often generate stress for expatriate staff, leaving them in a state where they are unable to perform their work to satisfactory levels (Bader \& Schuster 2015; Oetzel \& Getz 2012), which might affect the profitability of the business, and may lead to business failure. Further, the literature contests that a terrorist 
attack often leads to business failure beyond the businesses or industries targeted. These effects include increased interruptions to supply chains, and to new government regulations and procedures, which are intended to reduce stem emergent threats (Bouchet 2004; Ketata \& McIntyre, 2008; Spich \& Grosse 2005).

The literature also suggests that the effects of terrorism are confined to a few businesses, and therefore, should not affect those businesses that are not directly affected by the incident. For example, Enderwick (2001) suggests that the airline and tourism industries were the main primary sectors affected following the September 11, 2001 (9/11 hereafter) attack in the United States (US). Further, some have also suggested that terrorism should not lead to business failure because businesses will quickly recover following an attack. For example, following 9/11, the US GDP dropped by only half a percentage point, while the stock market recovered all of its losses within a month (Abadie \& Gardeazabal, 2008; Becker \& Murphy, 2001). A study by Aslam and Kang (2015) found that the effect of a terrorist attack on the Pakistani stock market was short-lived, as the market recovered from the terrorist shock in just one day. The findings by Brounrn and Derwell (2010) and Nikkinen et al. (2008) also point to financial markets recovering quickly following an attack.

Further arguments about why terrorism should not result in business failure are centred on the assertion that multinational companies can manage terrorism risks to avoid business failure (Enderwick 2006; Oetzel \& Getz 2012), and through the knowledge development derived from such incidents, they can actually gain a competitive advantage. According to Gao et al. (2017), a business can manage the effects of terrorism by using their reputation as one of their many intangible assets, which can facilitate their long-run survival needs. It has also been suggested that multinational corporations (MNCs) can improve their chances of survival through the knowledge that they have acquired as a result of the terrorism threat (Petersen et al. 2008). Similarly, Suder et al. (2017a) find that HR practices, and the 
interventions adopted in hostile environments, play a critical role in leveraging the lessons learnt from addressing the terrorist threat; therefore, improving the resilience and efficiency of systems in other parts of the business that are unaffected, directly, by terrorism.

The paper also investigates whether terrorism has a different effect on business failure depending on whether the country is developed, developing, or fragile. This is for several reasons. First, there is anecdotal evidence that terrorism has different economic consequences in developed and developing countries - hence the suspicion that this may extend to business failure. For instance, the evidence by Cinar (2017) suggests that terrorism negatively affects economic growth particularly in low-income countries. The finding by Procasky and Ujah (2016), which is that terrorism results in a higher cost of debt, particularly, for developing markets, also suggests that there is a differential impact of terrorism on developed and developing countries. Second, the differences in resources between developed and developing countries are important, as the former have more resources that can cushion the effect of terrorism, such as applying monetary, fiscal and other policies to speed up the recovery from either a large-scale attack or a prolonged attack (Sandler \& Enders 2008). For example, the US Congress approved the introduction of an emergence insurance to cover the catastrophic losses that were experienced due to the effects of terrorism in the wake of the 9/11 attack (Kunreuther at al. 2003), which meant that some business failures were avoided.

Finally, terrorism may lead to more business failures in developing and fragile states, when compared to the cases in developed countries; this is because of the pervasiveness of ‘institutional voids' (Khanna \& Palepu 1997, 2005). This means that the institutional arrangements needed to support the normal functioning of the market are absent, weak, or fail to accomplish the role expected of them (Mair \& Marti 2009). This often results in the higher cost of doing business. Most fragile states are also characterised by a sustained degradation of the preconditions that are relevant for markets to exist, such as governance structure, rules of 
exchange (Fligstein 2001) and autonomy (McMillan 2002), as well as lacking the institutions needed for the market to function well (e.g., governance mechanisms, disclosure requirements, and functioning judiciary) (Rotberg 2003). We argue that the combination of a high security risk and severe institutional voids, where businesses are learning to adapt to dangerous and high-risk environments whilst operating and protecting staff and assets, makes fragile states an extreme business environment to operate in.

Panel data from 174 countries over the period 2009-2015 were used to achieve our objectives. The sample was then divided into 40 developed, 134 developing, and 39 fragile countries $^{5}$. To capture business failure, we adapted and used the World Bank's Doing Business' Resolving Insolvency index as a proxy. The results of the fixed-effects estimations show that terrorism has a significant positive impact on business failure. However, when the sample is divided into developed, developing and fragile countries, the results indicate that terrorism has a significant positive impact on business failure in developing and fragile countries, but not in developed countries. The marginal effects of the interactions with regional dummies of the fragile countries show that an increase in terrorist incidents by 100 will increase business failure by $1 \%$ and $0.7 \%$ points in the South Asia and SSA regions, respectively.

The study makes two main contributions to the literature on the impact of terrorism on economic outcomes. First, the study contributes by improving our understanding of the relationship between terrorism and business failure. This is significant given that, despite normative arguments suggesting a positive relationship (e.g., Enderwick 2001; Brodeur 2017) and no relationship (Aslam \& Kang 2015; Brounrn \& Derwell 2010; Enderwick 2001), there is no empirical evidence on whether terrorism leads to business failure. Second, the study also contributes by providing evidence that terrorism has a positive effect on business failure

\footnotetext{
${ }^{5}$ Note that there are overlaps in developing and fragile countries. That is, the sample of fragile countries also makes up the sample of developing countries.
} 
- but only in developing and fragile countries. The current finding of this study follows on from the limited evidence found in the literature (e.g., Blomberg et al. 2004; Cinar 2017) that shows that terrorism affects economic growth differently in developed countries when they are compared to developing countries.

The rest of this paper is structured as follows. Section 2 reviews the literature on terrorism and business failure. In Section 3, the data are defined, and the models outlined. Section 4 presents the empirical results followed by a discussion. The summary and conclusions are in Section 5.

\section{Literature Review}

2.1 Why terrorism should lead to business failure

Terrorism has direct and indirect effects on the performance of businesses, which may lead to their failure. For example, the direct effect of terrorism is the immediate effect experienced by individual businesses during a terror attack (Greenbaum et al. 2007; Knight \& Czinkota 2008; Suder 2004). This includes the immediate loss of lives and property, cost of rescue and rebuilding, and additional resources to prevent future terrorist attacks (Greenbaum et al. 2007; Lenain et al. 2002; Mueller \& Stewart 2014). Terrorism not only affects the physical destruction of a global business, but also indirectly alters the rank and value of global brands. By linking the threat of terrorism to the rank and value of 100 global brands after the 9/11 attack, Suder et al. (2008) find a significant moderation in the rank and value of global brands in the first five years after the 9/11 attack. Jain and Grosse (2009) contend that the overall psychological effect of the risk of a future terror attack, and the direct cost of increased airport security, have an adverse economic consequence on global business transactions. Other costs (including security and surveillance expenditure, delay in issuing visas, repairs, and replacement of stolen property) adversely deplete the financial resources of 
fragile states (Rotberg 2003), which may cause business failure. It is estimated that the 9/11 attacks cost US companies US\$30.7 billion in lost revenue just from the delaying of issuing visas to visitors, and to foreign business personnel travelling to the United States.

According to Jain and Grosse (2009), the increased uncertainty and risk relating to terrorism also create an unpredictable disruption in the supply- and value-chain operations, resulting in a slowing or shutting down of production lines, loss of revenue due to stock-outs, and higher insurance and transportation costs for a more expedient shipment among businesses. Businesses under such conditions rely more on firm strategy than on traditional risk management strategy to manage such a supply- and value-chain disruption so as to avoid any failure (Enderwick 2006). According to Wernick (2006), terrorism risk hurts the operation of multinational businesses or value-chain partners due to the disruptions it brings to the flow of resources (moving goods, money, people and information), leading to increased cost, time delay and missed opportunities.

The effects of terrorism have also been found to include the willingness of employees to work at certain times or on certain days of the week (Brodeur 2017; Greenbaum et al. 2007). For example, several studies (e.g., Warr, 2000; Wilcox et al. 2003) contend that the fear of violence could also cause changes in the routine activities of workers, and this change in behaviour translates into a greater cost to the business. According to Hamermesh (1999), the fear of crime reduces the willingness of employees to work at the weekends and during the evenings. As a result, businesses are more likely to offer higher wages to entice staff to work during these periods. Dreher et al. (2011) state that the fear and uncertainty in the aftermath of a terrorist attack also affects the individual migration decisions of skilled workers. This outcome is reinforced by the potential host countries who are increasingly resorting to quality-selective immigration policies, and prefer skilled over medium- and lowskilled immigrants (e.g., Docquier et al. 2007), making it relatively easy for just the skilled 
workers to leave their terror-ridden home countries for safer locations. Such conditions may lead to business failures due to the decline in human capital, which is needed to sustain the firm's operations (Amankwah-Amoah 2016; D’Aveni \& MacMillan 1990; Hambrick \& D’Aveni 1992).

In addition, operating in a terror-endangered area has a tremendously negative effect on the organisational commitment of the workforce (Reade \& Lee 2012). Overall, evidence suggests that global relocation involves many changes and stressful challenges and often exposes expatriates to various level of stress (Harrison et al. 2004; Shaffer \& Harrison 1998). Some of these challenges include learning a new language, adapting to different cultural norms, and establishing new social networks (Caligiuri, 1997; Selmer 2001). These challenges are multiplied by safety concerns that are linked to living in terrorism-endangered countries. Because there is often only limited support for those who relocate, this can lead to uncertainty and stress for expatriates, and affect the psychological wellbeing of those who are working in terrorism-endangered countries (Bader \& Schuster 2015; Oetzel \& Getz 2012). The post-traumatic stress, anxiety and feelings of insecurity result in the failure of most managers, who are assigned to terror-endangered countries, to be able to complete their tasks, or they underperform. For instance, Bader and Schuster (2015) analyse the impact of expatriate social networks on the psychological wellbeing of 175 expatriates working in four terrorism-endangered countries (Afghanistan, India, Pakistan, and Saudi Arabia). The evidence suggests that a large and diversified network positively affects the psychological wellbeing of international expatriates operating in these four regions that are exposed to terrorism. Similarly, Bader and Berg (2013) investigate how terror-induced stress affects the attitude and performance of 143 expatriate managers in high-risk countries. The evidence suggests that terror-induced stress lowers the expatriates' work attitude and their attitude 
towards their host country nationals (disaffection). This eventually impedes their performance and may lead to business failure.

It has, however, been suggested that terrorist attacks only affect a few businesses, and therefore, should not be considered responsible for all business failures. For instance, following the 9/11 attack in New York, USA, Enderwick (2001) identified that only the airline and tourism sectors were most affected by it. According to Enderwick the attack had an immediate impact on the propensity for, and the cost of, airline travel, given that the terrorists had utilised commercial aircrafts to carry out the attack, which then hurt the tourism sector. The higher level of uncertainty resulted in higher security costs and delays, which by implication had a differential adverse effect on the productivity of short-haul carriers and the growth of the tourism sector. For instance, in anticipation of the drop in orders following the 9/11 attack, Boeing and other major airlines announced layoffs of between 20,000 and 30,000 staff, while others such as Air Canada, which depended heavily on the US market, grounded several planes.

Although, a terrorist attack directly affects only a few businesses, some have suggested that it can lead to business failure beyond the businesses that are attacked, because the indirect effects of terrorism have a tendency to be widely felt. These effects include a decline in buyer demand, increased inter-business transaction costs, interruptions in international supply chains, decline in foreign direct investment (FDI), and the imposition of new government regulations and procedures intended to manage emergent threats (Barth et al. 2006; Bouchet 2004; Czinkota et al. 2004; Lenain et al. 2002; Spich \& Grosse 2005). For instance, the fear of terrorism heightens the level of uncertainty in the market, which adversely affects consumer behaviour and the businesses' investment decisions (Becker \& Rubinstein 2004; Drakos 2010). 
Becker and Rubinstein (2004) argue that the fear of terrorism heightens the level of uncertainty in the market, which in turn adversely affects consumer behaviour and investment decisions. According to Sandler and Enders (2008) the immediate cost of terrorism is localised, resulting in a substitution of economic activities from relatively vulnerable sectors to relatively safer sectors. This substitution allows large diversified businesses to cushion their losses. In an open economy, the intensity of terrorism is likely to force the large movement of international investments to avoid other types of risk (Enderwick 2006). A portion of such expensive investment is again used to support anti-terrorism measures raising, further, the costs of capital and the transactional costs of doing business.

The substitution argument is supported by the results from several studies (e.g., Abadie \& Gardeazabal 2008; Abadie \& Dermsi 2008; Suder \& Czinkota 2007). For example, Abadie and Gardeazabal (2008) find that the increased level of uncertainty associated with terrorism causes a large movement of international capital across countries in an attempt by international investors to avoid other types of countries' risk. This eventually results in low levels of return on investment due to the lack of productive capital to support business operations. Following 9/11, Suder and Czinkota (2007) find a significant increase in the migration of investment to less risky countries with a more expensive capital requirement for investment in risky countries. Similarly, Abadie and Dermsi (2008) suggest that vacancy rates, in the three most distinctive landmark buildings in Chicago and their vicinities, increased, when compared to other areas post 9/11, which suggested that economic activity in the Central Business Districts can be greatly affected by any changes, perceived, concerning the level of terrorism.

According to Gaibulloev and Sandler (2009), transnational terrorism has growthlimiting effects on terror-prone countries. This may lead to more business failures in such countries as it reduces growth by crowding-in government expenditures. Lenain et al. (2002) 
contend that, during periods of terror attacks, resources devoted to improving security in both the public and private sectors may crowd-out more productive spending, thus raising the cost of capital and labour. Such adverse business conditions increase the likelihood of business failures, both in the short run and in the long run (Liu 2009).

2.2 Why terrorism should not lead to business failure

Despite most evidence suggesting that terrorism may lead to business failure, some have suggested that it should not have much impact, since businesses quickly recover after the attack. For example, some have stated that a terrorist attack destroys only a small fraction of the stock of capital of a country (Abadie \& Gardeazabal 2008; Becker \& Murphy 2001). For example, after 9/11, the US GDP dropped by only half a percentage point, while the stock market recovered all its losses within a month. Similarly, after the Paris attack in 2015, the CAC-40 closed just $0.1 \%$ lower on the day. Also, after the London attack in 2005, the markets bounced back within days. Consistent with this notion, Aslam and Kang (2015) find that although terrorist attacks hurt the Pakistani stock market, such an effect was only shortlived as the market recovered from the terrorist shock in one day. They also find evidence that the impact of the terrorist attack depends on the location and type of attack, with more severe attacks eliciting a more negative response from the Karachi Stock Exchange. Similarly, Brounrn and Derwell (2010) and Nikkinen et al. (2008) report that financial markets react strongly to terror events, but then recover swiftly and soon return to business as usual, depending on the sector.

Arif and Suleman (2017) find mixed positive and negative impacts of terrorism on the stock prices of different sectors on the Karachi Stock Exchange. Further, the fear of uncertainty under such conditions most likely creates a beneficial environmental jolt for businesses to thrive (Carter \& Auken 2006). For example, Zycher (2003) finds that, after the 
9/11 attack, there was a significant increase in demand for security- and technology-related businesses, whilst tourism-related businesses experienced a decline in demand. Drakos and Kutan (2003) also find a similar drop in demand for tourism in those Mediterranean countries that had experienced terror attacks, and a significant rise in those destinations that were deemed safer. Also, in another tourism-based study, Araña \& León (2008) report that the 9/11 attacks caused a shock to tourists' utility and that some destinations experienced a strongly negative impact on their image and attractiveness, while others upgraded due to the effects of the terrorism. Arin et al. (2008) provide evidence on the response to terror shocks by the stock markets of six countries (Indonesia, Israel, Spain, Thailand, Turkey and the UK). Their study findings show that terror has a significant impact on both stock markets and stock market volatility, and the magnitude of these effects is larger in emerging markets. Specifically, they found the impact on both stock markets and stock market volatility in Spain and the UK to be generally less affected by terror shocks, which suggests that the financial investors in these two countries are more resilient to these events. This result can be explained by the investors' awareness of the higher institutional quality in Western democracies, and implies that relevant authorities might absorb the shocks caused by terrorist attacks to the financial markets, as suggested by Johnston and Nedelescu (2006).

According to the resource-based view (RBV) theory of the firm, a business can avoid failure, even if it is affected by terrorism, by developing distinct resources and hard-toimitate, rare, and valuable capabilities which will increase its survival probability, and which drives superior performance by generating a sustainable competitive advantage (Barney 1991). Any failure in any of these resources and capabilities adversely affects the organisation (Mellahi \& Wilkinson 2010). Knight et al. (2008) argue that businesses with better resources are in a good position to, and more likely to, respond to terrorism. In his integrative process model of organisational failure, he identified an array of external factors 
and internal factors precipitating organisational failure. According to Amankwah-Amoah (2016), these external factors are industry-specific and environmental factors, which the businesses have less control over. Terrorism can result in external environmental jolts, which are difficult to foresee, but these can cause a significant disruption to business and also potential business failure. Tirole (1988) contends that businesses, which cannot fit in with the demands of their environment, are often either "selected out" or "die". Therefore, the effect of terrorism on business failure may depend on the resources available to each business. Specifically, those with more resources are likely to survive the effects of a terrorist attack, while those with fewer resources are likely to fail.

The other argument for suggesting that terrorism should not lead to business failure is that businesses will try to manage the effects of terrorism. For instance, Harvey (1993) finds that fewer than $50 \%$ of MNCs had a formal programme to deal with terror attacks. However, a survey by Pricewaterhouse Coopers (2004) identified that 30\% of global CEOs recognised terrorism as one of the biggest threats facing their organisations. This means that businesses consider that proactively responding to violent conflict is strategically important for their performance and legitimacy (Kolk \& Lenfant 2010; Oetzel \& Getz 2012) and to avoid business failure (Enderwick 2001, 2006; Kolk \& Lenfant 2016; Oetzel \& Getz 2012; Shrivastava 2005).

In his work on managing the new global threats, Enderwick (2006) emphasises the need for businesses to focus more on strategy than on the traditional risk management approaches of managing new global threats. These key strategic responses include supply chain management, diversification and scenario planning, and ensuring business continuity. Shrivastava (2005) presented a crisis management framework for understanding the organisational and social processes, and causes and consequences of terrorism. Shrivastava (2005) suggests that having such an expanded view of terrorism affords policy makers in 
government and private organisations a better opportunity of identifying preventive measures to reduce the impact of terrorism on businesses and economic activities. On the question of why and how businesses respond to violent conflicts, Oetzel and Getz (2012) suggest that the proximity of stakeholders affects the strategy that businesses are likely to adopt in response to a conflict. The authors find that; whereas, local stakeholder pressure is associated with the likelihood that businesses will respond directly to violent conflict, and also collaborate with other organisation(s) or work alone, international stakeholders will respond indirectly to conflicts.

There has also been a suggestion that businesses can alleviate the effects of terrorism by using their reputation as one of many intangible assets, which can facilitate its long-run survival needs (Gao et al. 2017). Favourable reputation can help a firm realise the potential of its resources, therefore, enhancing its ability to attract and retain strategic human capital (Turban \& Cable 2003), as well as lowering its cost of capital, increasing its ability to raise financing (Stuart at al. 1999), increasing its ability to choose high-quality partners (Dollinger et al. 1997) and form alliances (Stern et al. 2014), and helping mitigate the impact of negative events (Love \& Kraatz, 2009). According to Gao et al. (2017), businesses can explore their reputation through their brands to gain a competitive advantage in emerging markets and to overcome institutional voids to assure long-run survival. To assess this reputation, buyers "tend to use brand names as signals of quality and value and often gravitate to products with brand names they have come to associate with quality and value” (Herbig \& Milewicz 1995: 8). Brands can also induce economies of scale in generating and spreading reputation; for example, a firm with a favourable reputation due to its high-quality performance in one product can transfer that positive reputation to another product via its brand name (Moorthy 1985). 
Several prior studies have also explored how the MNCs operating in failed states can improve their chances of survival from a HRM perspective (Czinkota et al. 2010; Suder 2006; Suder et al. 2017a, 2017b). Knowledge development through the internationalisation of foreign markets has been recognised by prior studies as a prerequisite for market expansion, competitive advantage, and increased resource commitment, which are relevant for the long-run survival needs of these businesses (see Johanson and Vahlue (1997) and Petersen et al. (2008)). Recently, Suder et al. (2017a) adopt an in-depth case study approach to provide an understanding of the role of 'rare' knowledge and the mechanisms that link the knowledge paths of MNCs operating in failed states. The key findings of the study suggest that HR practices and interventions adopted within hostile environments, with the expatriates' willingness to learn and share new knowledge, play a critical role in the creation, capturing and leveraging of rare knowledge used by MNCs for their long-run survival needs. Firing et al. (2015) also highlight potential ways through which businesses can capture and leverage knowledge classified as 'rare' through HR interventions, such as debriefing, so more can be learned from experiences gained during extreme events. Given that there are reasons for expecting terrorism to either lead or not to lead to business failure, we formulate the alternative hypotheses predicting a positive relationship between terrorism and business failure. It is, therefore, hypothesised that:

$\mathrm{H}_{1}$ : Terrorism is positively associated with global business failure $\mathrm{H}_{1 \mathrm{a}}$ : Terrorism is positively associated with business failure in developed countries $\mathrm{H}_{1 \mathrm{~b}}$ : Terrorism is positively associated with business failure in developing countries $\mathrm{H}_{1 \mathrm{c}}$ : Terrorism is positively associated with business failure in fragile countries

\subsubsection{How the effect of terrorism may differ due to institutional voids}


Although, we have discussed why terrorism might lead to business failure, the effect of terrorism may not be the same for all countries because of institutional voids. For example, it is well documented that MNCs operating in terrorism-endangered countries, such as failed states, are often faced with pervasive institutional voids (Gao et al. 2017; Khanna \& Palepu 1997, 2005). Most fragile states are often perceived to be riskier due to their pervasive inability to control their own national borders, or project power throughout their national territory, and they continually face the threat of secession, civil war, and large-scale violent internal struggles for control between the government and one or more non-state actors (Rotberg 2003). These countries also lack institutions that can help facilitate market transactions (Khanna \& Palepu 2010). For example, banks cannot always assure credit to businesses; and the absence of a rule of law means that courts cannot guarantee the enforcement of intellectual property rights (Gao et al. 2017).

Since institutional voids are more likely to occur in developing and fragile countries than in developed countries, it is possible that the impact of terrorism on global business failure may differ. This is based on the reasoning that developed countries have recovered quickly from the effects of terrorism, when compared to developing and fragile countries, due to differences in resources. However, despite such reasoning, there is no empirical evidence on whether terrorism has a different effect on business failure in developed, developing, and fragile countries where terrorism incidents are ongoing. Therefore, this paper adds to the existing literature by providing the evidence of how terrorism affects global business failure in developed, developing and fragile countries. Based on the on-going evidence, we develop the following hypotheses:

$\mathrm{H}_{2}$ : The impact of terrorism on business failure is more in developing and fragile countries due to prevalent institutional voids

\section{Sample Construction and Empirical Methods}




\subsection{Sample construction}

There are 195 countries in the world, which consist of 193 countries that are member states of the United Nations and 2 countries that are non-member observer states. However, being constrained by the unavailability of some of the countries' data we employ a panel of 174 countries and independent territories for the period 2009 to 2015. This is because comprehensive data for the World Bank’s Doing Business' resolving insolvency index, which we adapt and use as a proxy for global business failure, was not available prior to 2009.

The sample of countries was further partitioned into developed, developing, and fragile countries. The fragile countries were systematically chosen because they are ranked high in the failed states index ${ }^{6}$ as well as being terror-prone. For example, although countries such as Zimbabwe, North Korea and others are ranked high on the failed index, they are, however, not terror-prone. Similarly, the UK, France, and others, which are terror-prone, are not ranked high in the failed states index. Finally, fragile countries' regional dummies for Sub-Saharan Africa (SSA), South Asia and the Middle East and Northern Africa (MENA) were interacted ${ }^{7}$ with the terrorism to investigate the marginal differences of the impact of these variables on business failure in these regional sub-samples. These regions (SSA, South Asia and MENA) are the most terror-prone in the top-ranked category of the fragile states index (Okafor \& Piesse 2017). The countries in these regions also contribute to a very significant share of terrorist incidents. The data used were sourced from the Global Terrorism Database (GTD) and World Bank Development Indicators (WBDI). In addition, all variables were winsorised at the $1 \%$ level (Rahaman 2011) to reduce the influence of outliers. The sample of countries employed in the data is shown in Table 1A and Table 1B.

\footnotetext{
${ }^{6}$ See the FSI (2017) report for fragile states ranking.

${ }^{7}$ An interaction is formed as a product of two (or more) variables. An important application of the interaction variables is that it allows for differences in the slopes of two regression lines. For further reading, see Dielman (2005).
} 


\section{[INSERT TABLE 1 ABOUT HERE]}

\subsection{Variable description}

\subsubsection{Dependent variable}

The main variable of interest is a country-level business failure. Following the prior evidence of Shepherd et al. (2000, 2009), business failure occurs when a fall in revenues and/or a rise in expenses are of such a magnitude that the firm becomes insolvent and cannot attract new debt or equity funding; it cannot continue to operate under the current ownership and management conditions. However, due to the unavailability of firm-level data on business failure, in most of the developing and fragile countries, we adapted and used the resolving insolvency index obtained from the World Bank Doing Business database. According to the methodology used by the Word Bank, countries that obtain a higher score on the index (expressed as a percentage) have high recovery rates by secured creditors through reorganisation, liquidation or debt enforcement proceedings, and are more likely to have businesses operating in those countries that are able to survive when compared to those countries that have lower scores. Given that our study is more interested in business failure than in survival, we adapted this index, so that it can be interpreted on the basis of the chances of business failure rather than survival. We achieved this by subtracting the resolving index percentage from 100 for each country. By so doing, we ended up with an index, which is an inverse of the World Bank Doing Business resolving insolvency. According to this adapted index, businesses that operate in countries that have a higher index score are more likely to fail.

The World Bank Doing Business' resolving insolvency index was adapted and used as a proxy for business failure for the following reasons. First, when businesses fail, they 
become insolvent (Thomson, 1991). Thus, countries with weak insolvency resolving laws cannot stimulate the reorganisation of businesses, thereby, leading to business failures (Dewaelheyns \& Van Hulle 2008). Second, weak resolving insolvency laws cannot save struggling businesses when it is possible to do so, or reallocate the insolvent resources of failing businesses more productively. This is because investors and entrepreneurs will be less willing to commit to productive activities when they know they might be putting their entire personal fortunes in jeopardy (Cirmizi et al. 2011). For example, if it was not for the effective and robust insolvency resolving framework in Japan, then some of their struggling banks would not have been reorganised or absorbed by the stronger banks (Imai, 2009; Hoshi, 2002). Third, a weak resolving insolvency framework increases the cost of capital and is not able to mitigate against the weak mechanisms that are often responsible for business failures. Finally, a weak resolving insolvency framework cannot allow for a systematic approach that reduces ineffective debt recovery processes, thus weakening the investment climate (World Bank 2017).

\subsubsection{Independent variable}

Our main independent variable is terrorism, which is measured by the number of terrorist incidents, as defined in Table 2, together with the dependent and control variables. Similar to the study by Greenbaum et al. (2007), our study adopts the US military definition of terrorism, namely, "the threat or actual use of illegal force or violence to attain a political, economic religious or social goal through fear, coercion or intimidation” (LaFree and Dugan, 2002, p. 16). The US military definition of terrorism is one of the broadest of the definitions used in the creation of open source databases, and is including threats as well as actual violence, and social, religious and economic motives as well as political ones. Businesses in fragile and terror-prone countries face a significant number of terror threats and 
actual violence for a range of social, political and economic reasons. These threats and incidents of violence result in both direct and indirect costs, which hurt business growth and survival (see Greenbaum et al. (2007), Knight \& Czinkota (2008), Lenain et al. (2002) and Mueller and Stewart (2014)).

\section{[INSERT TABLE 2 ABOUT HERE]}

\subsubsection{Control variables}

The study also controls for several variables that impact business failure. These variables are mainly a proxy for financial development. According to the available literature, financial development has positive implications for an economy's long-run level of real activity (Boyd et al. 2001). Financial development comes with better economies of scale, increased supervision and regulation, and sustainable competition. These, we argue, mitigate against the survival and growth of businesses, since there will be higher levels of GDP, higher levels of savings, lower levels of inflation, efficient lending rates, and greater availability of credit within that economy. Banks and other lending institutions often create loans from savings. This means that business is less likely to be credit-constrained in the countries that have better economic growth rates, and where there is the availability of savings and credit. According to Detragiache et al. (2008), studies have shown that businesses benefited, immensely, in terms of profit through an increase in loan size. Tsoukas (2011) also shows that financial development played an important role in firm survival. That is, more liquid markets improved the survival chances of businesses. In contrast, inflation and high lending rates can erode the profit and increase the cost of doing business, respectively. The latter can also imply that businesses find it difficult to access credit, thus experiencing a fall in competitiveness, cost efficiency, and survival rates.

3.3 Preliminary data analysis 
Tables 3A and 3B show the descriptive statistics of the variables used. On average, $56.32 \%$ of the businesses in a particular country are likely to fail. The minimum is at about the $0.14 \%$ point (which is Japan in 2013), while the maximum is at about the $99.95 \%$ point (which is Zimbabwe in 2009 and 2010). The results also show a big difference in the average percentage of businesses likely to fail between developed countries (30.80\%) and developing countries (65.22\%). The results of the fragile countries' sub-sample in Table 3B show that, on average, $66.54 \%$ of the businesses are likely to fail, and the figure is slightly higher than that of the developing countries. The minimum for the fragile countries is $22.32 \%$ (Colombia in 2012) and the maximum is 96.61\% (Rwanda in 2013). Furthermore, the descriptive statistics show that at the mean, MENA (65.89\% point) and South Asia (64.31\% point) have a slightly lower business failure rate when compared to SSA (71.14\% point).

\section{[INSERT TABLE 3A \& 3B ABOUT HERE]}

Regarding the terrorism incidents, about 53 terrorist incidents were recorded over the period under review in the overall sample of countries. If disaggregated into developed, developing and fragile countries, the average numbers of terrorist incidents for the period are about 8, 71 and 218, respectively. For the fragile countries, of the three regions ${ }^{8}$ studied, SubSaharan Africa (SSA) has the lowest number of terrorism incidents at 43, South Asia and Middle East has the highest number at 572, and North Africa (MENA), on average, recorded 312 incidents.

The correlation coefficients are in Tables 4A and 4B. The coefficients of the independent variable do not suggest that there would be problems of multicollinearity in our study. In contrast to expectations, terrorism has a weak association with our measure of business failure, both in the global and fragile country samples. The control variables

\footnotetext{
${ }^{8}$ World regional classifications according to the World Bank are as follows; East Asia and Pacific, Europe and Central Asia, Latin America \& the Caribbean, MENA, North America, South Asia, and SSA.
} 
suggested a moderate association with our measure of business failure, although, and since correlation is not causality, the magnitude of these coefficients will have limited implications in our regression analysis.

\section{[INSERT TABLE 4A \& 4 B ABOUT HERE]}

\section{Empirical Approach}

4.1 The baseline specification and method

The analysis was estimated using the fixed-effects technique, as this was the most preferred by the Hausman test ${ }^{9}$ as against the Random-effects technique. The estimated technique employed in this study has advantages. First, the fixed-effects can help eliminate the risk of biased estimates because of heterogeneity across countries. Second, the fixedeffects can allow for constant slope coefficients, but with different intercepts for the individual countries. Third, the cross-section and the time dimensions of the data add more explanatory power to the estimation by allowing for higher degrees of freedom (Baltagi 1995; Gujarati 2004). The fixed-effects model can be estimated as follows,

$$
y_{i t}=\alpha_{i}+\beta X_{i t}+\mu_{i}+v_{i t}
$$

where $y_{i t}$ is business failure in country $i$ at time $t . X$ is a matrix of independent and control variables and $\beta$ are the coefficients to be estimated. $\mu_{i}$ and $v_{i t}$ represent the disturbance term - country-specific effects and random errors distributed. An expanded version of equation (1) is expressed as

$$
\begin{aligned}
& \text { Business failure }_{i t}=\alpha_{i}+\beta * \text { Terrorism }_{i t}+\beta * \text { GDP }_{\text {growth }}+\text { f }_{i t}+\beta_{*} \text { Savings }_{i t}+\beta * \\
& \text { Inflation }_{i t}+\beta
\end{aligned}
$$

\footnotetext{
${ }^{9}$ Hausman is a general test for specification of an econometric model that is applied to test for the appropriateness between the random and the fixed-effects models (Nerlove 2005).
} 
The model was first estimated for the entire sample. Disaggregating the sample into developed, developing, and fragile countries followed this. Finally, regional (SSA, South Asia and MENA) dummies were interacted with terrorism in order to observe differences in the marginal effects across these regional sub-samples. The inclusion of the regional dummies of SSA, South Asia and MENA is due to countries in these regions being the most terror-prone in the top ranked category of the fragile states index (Okafor \& Piesse 2017). Also, according to the sample data, these countries contribute a very significant share of terrorist incidents.

Regarding other specification tests, a Breusch-Pagan/Cook-Weisberg Test for heteroskedasticity indicated no presence of heteroskedasticity and, therefore, robust standard errors were not used to relax the assumptions that the errors were both independent and identically distributed. The period of the panel data is short; hence, a unit root test and cointegration are not suitable. These tests are best suited for time-series studies. The GMM estimates across the estimations were not consistent due to the inefficiency of estimates and the instruments (Baltagi 2013). Therefore, the fixed-effects test assumes the most consistent results, and our results and discussions are based on its estimates.

\subsection{Empirical evidence}

The main results of the relationship between terrorism and country-level global business failure are shown in Table 5. The results of all of the countries in our sample in Table 5 (Model 1) show that the model explains $45.37 \%$ of the variation in business failure. The results, which show a positive and significant relationship between terrorism and business failure, mean that hypothesis $\mathrm{H}_{1}$ of the study is supported, and is consistent with the arguments and on-going evidence of the impact of terrorism on business failure. The result 
suggests that high terrorist activities are more likely to contribute to high business failure, as countries would not be able to effectively resolve and mitigate against the insolvency of businesses.

In order to test for hypothesis $\mathrm{H}_{1} \mathrm{a}$, we disaggregate the analysis into developed, developing and fragile terror-prone countries. Evidence of the results of the fixed effect regressions is presented in Model 2, 3 and 4 of Table 5 for developed, developing and fragile terror-prone countries, respectively. The results in Table 5, Model 2, show that although terrorism and business failure are positively related, the relationship is not significant. Hypothesis $\mathrm{H}_{1 \mathrm{a}}$ is therefore not confirmed. Consistent with our expectations, the results in Models 3 and 4 of Table 5 show that terrorism is positive and significantly related to business failure in developing and fragile countries. This means that hypotheses $\mathrm{H}_{1 \mathrm{~b}}$ and $\mathrm{H}_{1 \mathrm{c}}$ are confirmed. The fact that there is a significant and positive relationship between terrorism and business failure in developing and fragile countries, but not in developed countries, means that high terrorist activities are more likely to contribute to high business failure among businesses operating in developing and fragile terror-prone countries, which supports hypothesis $\mathrm{H}_{2}$.

To gain further insights into the effect of terrorism on global business failure, we explored the marginal effects of terrorism in our sample of fragile countries, which we subdivided into SSA, South Asia and MENA countries. The results in Table 6 show that an increase in terrorist incidents by 100 will increase the chances of business failure by $0.7 \%$ and 1\% points for SSA and South Asian countries, respectively. Surprisingly, the marginal effects of MENA countries were insignificant. Nevertheless, the larger marginal effect of South Asia was expected considering that the region contributes, overall, to a considerable share of terrorism. 


\section{[INSERT TABLES 5 \& 6 ABOUT HERE]}

The finding that terrorism has a significant impact on the business failure regarding the pooled countries is consistent with Kollias et al. (2011) who suggest that terrorism has multiple economic consequences that may be detrimental to the survival of the businesses. The positive effect of terrorism on business failure also follows the normative arguments that terrorist attacks increase the business costs (e.g., Brodeur 2017; Enderwick 2001) that may contribute to business failure, and in our study, this is shown through its impact on weakening the ability of countries to effectively manage insolvency issues. Therefore, our findings provide the evidence that supports the suggestion that terrorism can lead to business failure, because it results in a decline in the ability of countries to sustain an effective framework for resolving insolvency.

The findings that terrorism has a different impact when our sample is partitioned into developed, developing, and fragile countries are significant. For example, the finding that terrorism has no significant negative effect in developed countries follows the notion that developed countries have more resources than developing countries, which they use to minimise the disruption caused by terrorism and help businesses to recover (Sandler \& Enders 2008). Arin et al. (2008), for example, find that the response to terror attacks varies across the developed and developing countries in that developed countries (UK, Spain) were less affected than the developing countries. The evidence of differences in the impact of terrorism on developed countries when compared to developing countries and fragile countries can also be explained in terms of the institutional voids that often exist in developing and fragile countries. Developing countries - but particularly fragile countries are often characterised by a sustained degradation of the preconditions that are relevant for the markets and for effective institutions to exist; which are governance structures, and the 
rule of law, which in turn may weaken the sustainable macroeconomic frameworks used for managing the insolvency index, and thus, cause an increase in business failure.

On the control variables, GDP was negative and insignificant except for the developing country sample. Findings by Ahmad et al. (2009) also show that GDP reduces the corporate failure in their study. An increasing GDP indicates that businesses would, on average, record higher levels of profit, which has a propensity for lowering business failure. With respect to our findings, an increasing GDP would mean that countries are able pursue a regulatory macroeconomic framework that can help mitigate against insolvency issues. Savings was positive and significant in all the models. The positive relationship of this measure of financial development is not expected because financial development improves business survival through better and sustainable frameworks, which are used for managing insolvency. However, there could be several reasons for this. First, there is a possibility that the thresholds of savings in these regions are not at the required levels to allow for an effective reallocation of productive resources and the investment decisions necessary for an effective solvency framework. Second, savings could have been directed to other economic activities besides those of managing insolvency activities. Although, these lines of arguments were not being established in this study, as they were only theoretically used to lend support to the findings. Inflation was positive but only significant in the developing and fragile country samples. Inflation erodes macroeconomic frameworks and adds costs to the effective operations of governments. Lending rate was only positive and significant in the entire sample and developing country estimations. To some extent, this shows that increases in lending rates can lead to business failure. Increasing lending rates can also mean that the cost of capital is higher and debt recovery processes are less effective, leading to the liquidation of businesses. The availability of credit was negative and significant in all the models. The ease of capital access by businesses helps promote corporate investment and enables countries to 
have frameworks that easily allow businesses to renegotiate their terms of credit, thereby, reducing the costs of financial distress (Djankov et al. 2005). This would mean that the insolvency issues are managed, and hence, there is a reduction in business failure.

\section{Conclusion and Policy Implications}

This study presents an empirical investigation that is considering the impact of terrorism on business failure using a sample of 174 countries. To determine whether terrorism had different impacts on business failure we divided the sample into developing, developed and fragile countries. The results of the fixed estimations show that terrorism has a significant positive effect on business failure among the entire sample of 174 countries. However, when the sample is partitioned, the results indicate that terrorism has a significant positive impact on business failure in developing and fragile countries but not in developed countries. The marginal effects of the fragile states sample show that an increase in terrorist incidents by 100 will increase business failure (insolvency index) by $1 \%$ and $0.7 \%$ points in the South Asia and SSA regions, respectively.

The results of our study should be interpreted in the light of the limitations of the study. For example, due to data availability, our study is limited to a seven-year period. Also, despite the finding that terrorism is associated with business failure in the full sample, for both the developing and fragile countries, it is possible that there may be other explanatory variables not included. This is especially so in respect of the fragile countries where so many other variables can contribute to business failure. Finally, the impact of terrorism on business failure might be best captured at a sectorial level, as this will enable the characteristics of individual sectors to be modelled; however, due to data unavailability our study was unable to achieve this. This could be an avenue for future research. 
Despite the limitations, our results contribute to the academic literature on terrorism and its impact on business failure and have policy implications. First, we offer new evidence of the relationship between terrorism and business failure using a global and more representative sample. The evidence suggests that, beyond losing life and personal injuries that the victims of terrorist actions suffer, and the atmosphere of fear that terrorists seek to create with their premeditated use of brutal violence, terror also has an adverse effect on the survival of businesses by weakening the macroeconomic frameworks, such as those that can help with managing insolvency issues. The results also contribute by providing new evidence that terrorism has a different impact in developed countries compared to developing countries and fragile states. In terms of the policy implications, our findings suggest that policy makers should be concerned about the economic consequences of terror attacks on macroeconomic and institutional frameworks, such as those related to managing the insolvencies of businesses no matter how small the terror attack is. We argue that such attacks impact on the business environment of countries and lead to business failure. Some channels through which this can occur may include the inability of economies to implement and sustain effective insolvency resolving laws and frameworks, the inability of business to have their insolvent resources reallocated, and the unwillingness of entrepreneurs to commit to productive activities.

\section{References}

Abadie, A. \& Gardeazabal, J., (2008). Terrorism and the world economy. European Economic Review, 52(1), 1-27.

Abadie, A. and Dermisi, S. (2008). Is Terrorism Eroding Agglomeration Economies in Central Business Districts? Lessons From the Office Real Estate Market in Downtown Chicago, Journal of Urban Economics, 64(2), 451-463.

Ahmad, A.H., Daud, M., Ahmad Rizal Mazlan, A.R., and Marzuki, A. (2009). Macroeconomic determinants of corporate failures in Malaysia. International Journal of Business and 
Management, 3(3),38-49.

Amankwah-Amoah, J., (2016). An integrative process model of organisational failure. Journal of Business Research, 69(9), 3388-3397.

Araña, J. E., and León, C. J., (2008). The impact of terrorism on tourism demand. Annals of Tourism Research, 35(2), 299-315.

Arif, I., \& Suleman, T. (2017). Terrorism and stock market linkages: An empirical study from a front-line state. Global Business Review, 18 (2), 365-378.

Arin, K., Ciferri., D and Spagnolo, N (2008). The price of terror: The effects of terrorism on stock market returns and volatility. Economics Letters, 101(3),164-167.

Aslam, F., \& Kang, H. G., (2015). How different terrorist attacks affect stock markets. Defence and Peace Economics, 26 (6), 634-648.

Bader, B. \& Berg, N., (2013). An Empirical Investigation of Terrorism-induced Stress on Expatriate Attitudes and Failure. Journal of International Management, 19(2), 163-175.

Bader, B. \& Schuster, T., (2015). Expatriate social networks in terrorism-endangered countries: An empirical analysis in afghanistan, india, pakistan, and saudi arabia. Journal of International Management, 21(1), 63.

Baltagi, B., (2013). Econometric Analysis of Panel Data. John Wiley \& Sons Ltd, UK.

Barney, J. B., (1991). Firm resources and sustained competitive advantage. Journal of Management, 17, 99-120.

Barth, J., Li, T., McCarthy, D., Phumiwasana, T., \& Yago, G., (2006). Economic impacts of global terrorism: from Munich to Bali. In: Mrudula, E. (Ed.), Terrorism: Global Economic Impact. Icfai Books, New York, 27-60.

Becker, G. \& Murphy, K., (2001). Prosperity will rise out of the ashes. Wall Street Journal, October 29, 2001.

Becker, G.S. \& Rubinstein, Y., (2004). Fear and the Response to Terrorism: An Economic Analysis. Mimo, (October 2003), 1-90.

Blomberg, S.B., Hess, G.D. \& Orphanides, A., (2004). The Macroeconomic Consequences of Terrorism. Journal of Monetary Economics, 51(5), 1007-32.

Bouchet, M., (2004). The impact of geopolitical turmoil on country risk and global investment strategy. In G. Suder (Ed.), Terrorism and the international business environment: The security-business nexus: 83-104. Cheltenham, UK: Edward Elgar.767-790.

Boyd, J. H., Levine, R., \& Smith, B. D., (2001). The Impact of Inflation on Financial Sector Failure. Journal of Monetary Economics, 47(2), 221-248.

Brodeur, A., (2017). The Effect of Terrorism on Employment and Consumer Sentiment: Evidence from Successful and Failed Terror, American Economic Journal: Applied Economics, 9526, 48.

Brounrn, D., \& Derwell J., (2010).The Impact of Terrorist Attacks on International Stock Markets. European Financial Management, 16(4), 585 - 598.

Caligiuri P.M., (1997). Assessing expatriate success: Beyond just "being there.” In Saunders DM, Aycan Z (Eds.), New approaches to employee management. Greenwich, Cl: JAI Press. 4, 117- 140 .

Carter, R., \& Auken, H. Van, (2006). Small Firm Bankruptcy. Journal of Small Business Management, 44(4), 493-512.

Çinar, M. (2017). The effects of terrorism on economic growth: Panel data approach. Zb.rad. Ekon. fak. Rij. 35(1) 97-121.

Cirmizi, E., Klapper, L., \& Uttamchandani, M., (2011). The Challenges of Bankruptcy Reform. The World Bank Research Observer, 27(2), 185-203.

Czinkota, M., Knight, G., \& Liesch, P., (2004). Terrorism and international business: conceptual foundations. In: Suder, G. (Ed.), Terrorism and the International Business Environment: the Security-business Nexus. Edward Elgar, Nottingham, 43-57. 
Czinkota, M.R., Knight, G.A., Liesch, P.W., \& Steen, J. (2010). Terrorism and international business: A research agenda. Journal of International Business Studies, 41, 826-843.

D’Aveni, R.A., \& MacMillan, I.C., (1990). Crisis and the Content of Managerial Communications: A Study of the Focus of Attention of Top Managers in Surviving and Failing Firms. Administrative Science Quarterly, 35(4), .634.

Detragiache, E., Tressel, T., \& Gupta, P., (2008). Foreign Banks in Poor Countries: Theory and Evidence. Journal of Finance, 63(5), 2123-2160.

Dewaelheyns, N., \& Van Hulle, C., (2008). Legal Reform and Aggregate Small and Micro Business Bankruptcy Rates: Evidence from the 1997 Belgian Bankruptcy Code. Small Business Economics, 31(4), 409-424.

Dielman, T. E., (2005). Applied Regression Analysis: A Second Course in Business and Economic Statistics, CA: Brooks/Cole Thomson Learning.

Djankov, S., Jindra, J., \& Klapper, L. F., (2005). Corporate Valuation and the Resolution of Bank Insolvency in East Asia. Journal of Banking \& Finance, 29(8-9), 2095-2118.

Docquier, F., Lohest, O., \& Marfouk, A., (2007). Brain drain in developing countries. World Bank Economics Review, 21, 193-218.

Doing Business, 2017. Doing Business Data (C) The World Bank Group

Dollinger, M. J., Golden, P. A., \& Saxton, T. (1997). The effect of reputation on the decision to joint venture. Strategic Management Journal, 18(2), 127-140.

Drakos, K., \& Kutan, A.M., (2003). Regional Effects of Terrorism on Tourism in Three Mediterranean Countries. Journal of Conflict Resolution, 47(5), 621-641.

Drakos, K., (2010). Terrorism activity, investor sentiment, and stock returns. Review of Financial Economics, 19(3), 128-135.

Dreher, A., Krieger, T., \& Meierrieks, D., (2011). Hit and (they will) run: The impact of terrorism on migration. Economics Letters, 113(1), 42-46.

Enderwick, P., (2001). Terrorism and the international business environment. Academy of International Business, 1(3), 3-24.

Enderwick, P., (2006). Managing the new global threats. University of Auckland Business Review, 8(2), 63-72.

Firing, K., Moen, A., \& Skarsvåg, K. (2015). Debriefing to learn from extreme events: The case of Utøya. Leadership \& Organization Development Journal, 36(6), 78-89.

Fligstein, N., (2001). The architecture of markets: An economic sociology of twenty-first century capitalist societies. Princeton University Press, Princeton.

FSI, (2017). Failed States Index. (C) The Fund for Peace. Washington, DC.

Gaibulloev, K., \& Sandler, T., (2009). The impact of terrorism and conflicts on growth in Asia. Economics and Politics, 21(3), 359-383.

Gao, C., Zuzul, T., Jones, G., \& Khanna, T., (2017). Overcoming Institutional Voids: A Reputation-Based View of Long-Run Survival, Strategic Management Journal, 38, 21472167.

Ghemawat, P., (2003). Semi-globalization and the international business strategy, Journal of International Business Studies, 34(2), 138-52.

Greenbaum, R.T., Dugan, L., \& LaFree, G., (2007). The impact of terrorism on Italian employment and business activity. Urban Studies, 44(5-6), 1093-1108.

GTD, (2017). Global Terrorism Database. (C) National Consortium for the Study of Terrorism and Responses to Terrorism.

Gujarati, D. N., (2004). Basic Econometrics, Fourth Edition, McGraw-Hill.

Hambrick, D.C., \& D’Aveni, R.A. (1992). Top team deterioration as part of the downward spiral of large corporate bankruptcies. Management Science, 38(10), 1445-1466.

Hamermesh, D., (1999). Crime and the timing of work. Journal of Urban Economics, 45, 311330. 
Harrison, D. A., Shaffer, M. A., \& Bhaskar-Shrinivas, P., (2004). Going places: Roads more and less traveled in research on expatriate experiences. In J. J. Martocchio (Ed.), Research in Personnel and Human Resources Management, 23, 199-247.

Harvey, M. G., (1993). A survey of corporate programs for managing terrorist threats. Journal of International Business Studies, 24(3), 340-352.

Herbig, P., \& Milewicz, J., (1995). The relationship of reputation and credibility to brand success. Journal of Consumer Marketing, 12(4), 5-10.

Hoshi T., 2002. The Convoy System for Insolvent Banks: How it Originally Worked and why it Failed in the 1990s. Japan and the World Economy, 14(2), 155-180

Imai, M., 2009. Political Influence and Declarations of Bank Insolvency in Japan. Journal of Money, Credit and Banking, 41(1), 131-158.

Ismail, A., \& Amjad, S., (2014). Determinants of Terrorism in Pakistan: An Empirical Investigation. Economic Modelling, 37, 320-331.

Jain, S.C., \& Grosse, R., (2009). Impact of terrorism and security measures on global business transactions: Some international business guidelines. Journal of Transnational Management, 14(1), 42-73.

Johanson, J., \& Vahlne, J.E., (1997). The Uppsala internationalization process model revisited: From liability of foreignness to liability of outsidership. Journal of International Business Studies, 40 (9), 1411-1431.

Johnston, R.B., \& Nedelescu, O.M., (2006). The impact of terrorism on financial markets The impact of terrorism on financial markets. Journal of Financial Crime, 13(1), 7-25.

Ketata, I., \& McIntyre, J. (2008). Corporate social responsibility as a new orientation in response to crisis management of sea changes and dead reckoning. In G. Suder (Ed.), International business under adversity: 150-167. Cheltenham, UK: Edward Elgar

Khanna, T., \& Palepu, K. G., (2010). Winning in emerging markets: A road map for strategy and execution. Boston, MA: Harvard Business Review Press.

Khanna, T., \& Palepu, K., (1997). Why focused strategies may be wrong for emerging markets. Harvard Business Review, 75(4), 41-48.

Khanna, T., \& Palepu, K., (2005). Spotting institutional voids in emerging markets. Watertown, MA, U.S.A. Harvard Business School Press.

Knight, G.A., \& Czinkota, M.R., (2008) Terrorism and international business. Working Paper, August 2008.

Kolk, A., \& Lenfant, F. (2016). Hybrid business models for peace and reconciliation, Business Horizons, 59(5), 503-524

Kollias, C., Papadamou, S., \& Stagiannis, A., (2011). Terrorism and capital markets: The effects of the Madrid and London bomb attacks. International Review of Economics and Finance. 20 (2011), 532-541.

Kunreuther, H., Michel-Kerjan, E., \& Porter, B., (2003). Assessing, managing, andfinancing extreme events: dealing with terrorism. NBER Working Paper No. w10179, Cambridge MA, National Bureau of Economic Research.

Lenain, P., Bonturi, M., \& Koen, V., (2002). The economic consequences of terrorism. OECD Working Paper.

Love, E. G., \& Kraatz, M., (2009). Character, conformity, or the bottom line? How and why downsizing affected corporate reputation. Academy of Management Journal, 52(2), 314-335.

Mair, J., \& Marti, I., (2009). Entrepreneurship in and around Institutional Voids: A Case Study from Bangladesh, Journal of Business Venturing. 24, 419-435.

McMillan, J., (2002). Reinventing the bazaar: A natural history of markets.W.W. Norton, New York.

Mellahi, K., \& Wilkinson, A., (2010). Managing and coping with organizational failure: Introduction to the special issue. Group \& Organization Management, 35, 531-541. 
Moorthy, K. S., (1985). Using game theory to model competition. Journal of Marketing, 22(3), 262-282.

Mueller, J., \& Stewart, M.G., (2014). Evaluating Counterterrorism Spending. Journal of Economic Perspectives, 28(3), 237-248.

Nerlove, M., (2005). Essays in Panel Data Econometrics. Cambridge University Press. Cambridge, UK.

Nikkinen, J., Omran, M. M., Sahlstrom, P., \& Aijo, J. (2008). Stock Returns and Volatility Following the September 11 Attacks: Evidence from 53 Equity Markets. International Review of Financial Analysis, 17, 27-46.

Oetzel, J., \& Getz, K., (2012). Why and how might firms respond strategically to violent conflict? Journal of International Business Studies, 43, 166-186.

Okafor, G., \& Piesse, J., (2017). Empirical Investigation into the Determinants of Terrorism: Evidence from Fragile States. Defence and Peace Economics, 1-15.

Petersen, B., Pedersen, T., \& Lyles, M.A., (2008). Closing knowledge gaps in foreign markets. Journal of International Business Studies, 39, 1097-1113.

PricewaterhouseCoopers, (2004). 8th Annual Global CEO Survey. New York: PricewaterhouseCoopers.

Procasky, W.J., \& Ujah, N.U., (2016). Terrorism and its impact on the cost of debt. Journal of International Money and Finance, 60, 253-266.

Rahaman, M. M., (2011). Access to financing and firm growth, Journal of Banking \& Finance, 35(3), 709-723.

Reade, C., \& Lee, H.-J., (2012). Organizational commitment in time of war: Assessing the impact and attenuation of employee sensitivity to ethnopolitical conflict. Journal of International Management, 18(1), 85-101.

Rotberg, R.I., (2003). Failed States, Collapsed States, Weak States: Causes and Indicators. In State failure and state weakness in a time of terror, ed. R. I. Rotberg. Washington, D.C.: Brookings Institution Press.1, 1-26.

Sandler, T., \& Enders, W., (2008). Economic consequences of terrorism in developed and developing countries: An overview, in: Philip Keefer and Norman Loayza (eds.), Terrorism, Economic Development and Political Openness. Cambridge: Cambridge University Press.

Selmer, J., (2001). Psychological barriers to adjustment and how they affect coping strategies: Western business expatriates in China. International Journal of Human Resource Management, 12(2), 151-165.

Shaffer, M. A., \& Harrison, D. A., (1998). Expatriates' psychological withdrawal from international assignments: Work, nonwork, and family influences. Personnel Psychology, 51(1), 87-118.

Shepherd, D. A., Wiklund, J., \& Haynie, J. M., (2009). Moving forward: Balancing the financial and emotional costs of business failure. Journal of Business Venturing, 24, 134-148.

Shepherd, D.A., Douglas, E.J., \& Shanley, M., (2000). New venture survival: Ignorance, external shocks, and risk reduction strategies. Journal of Business Venturing, 15(5/6), 393-410.

Shrivastava, P., (2005). Managing Risks in the age of terror. Risk Management, 7(1), 63-70.

Spich, R., \& Grosse, R. (2005). How does homeland security affect US firms' international competitiveness? Journal of International Management, 11(4), 457-478.

Stern, I., Dukerich, J. M., \& Zajac, E., (2014). Unmixed signals: How reputation and status affect alliance formation. Strategic Management Journal, 35(4), 512-531.

Stuart, T. E., Hoang, H., \& Hybels, R. C., (1999). Interorganizational endorsements and the performance of entrepreneurial ventures. Administrative Science Quarterly, 44(2), 315-349.

Suder, G. (Ed.)., (2004). Terrorism and the International Business Environment. Northampton, MA: Edward Elgar Publishing.

Suder, G., \& Czinkota, M. (2007). Towards an understanding of terrorism risk in the MNE, 
Multinational Business Review, 13(3), 3-23. .

Suder, G., Reade, C., Rivierec, M., Birnikd, A., \& Nielsen, N., (2017a). Mind the gap: the role of HRM in creating, capturing and leveraging rare knowledge in hostile environments. International Journal of Human Resource Management, 5192(10), 1-28.

Suder, G.S., (2006). Corporate Strategies Under International Terrorism and Adversity. Edward Elgar Publishing Ltd., Northampton, MA.

Suder, G., Birnik, A., Nielsen, N., \& Riviere, M., (2017b). Extreme case learning: The manager perspective on rare knowledge and capabilities development. Knowledge Management Research \& Practice, 15,130-145.

Thomson, J. B., 1991. Predicting Bank Failures in 1980s. Economic Review-Federal Reserve Bank of Cleveland, 27(1), 9-20

Tirole, J., (1988). The theory of industrial organization. Boston, MA: MIT Press.

Tsoukas, S., (2011). Firm Survival and Financial Development: Evidence from Panel of Emerging Asian Economies. Journal of Banking and Finance, 35(7), 1736-1752.

Turban, D. B., \& Cable, D. M., (2003). Firm reputation and applicant pool characteristics. Journal of Organizational Behavior, 24(6), 733-751.

Warr, M., (2000). Fear of Crime in the United States: Avenues for Research and Policy. Measurement and Analysis of Crime and Justice, 4, 451-489.

WDI, (2017). World Development Indicators (WDI). (C) World Bank, Washington DC.

Wernick, D., (2006). Terror incognito: Is the new global terrorism a form of political risk? Paper presented at the 2006 Academy of International Business Annual Conference. East Lansing, MI: Michigan State University.

Wilcox, P., Land, K.C., \& Hunt, S.A., (2003). Criminal circumstance: a dynamic multi-contextual criminal opportunity theory. The Canadian Journal of Sociology, 29(1), 248.

World Bank, (2017). Insolvency and Debt Resolution. Availability at http://www.worldbank.org/en/topic/financialsector/brief/insolvency-and-debt-resolution. (C) The World Bank.

Zycher, B., (2003). A Preliminary Benefit/Cost Framework for Counterterrorism Public Expenditures Library of Congress Cataloging-in-Publication Data. Available at: http://www.rand.org/. 
Table1A

Sample Countries

This table presents the sample of countries employed for our analysis on the impact of terrorism on global business failure over the period 2009-2015. + is for developed countries

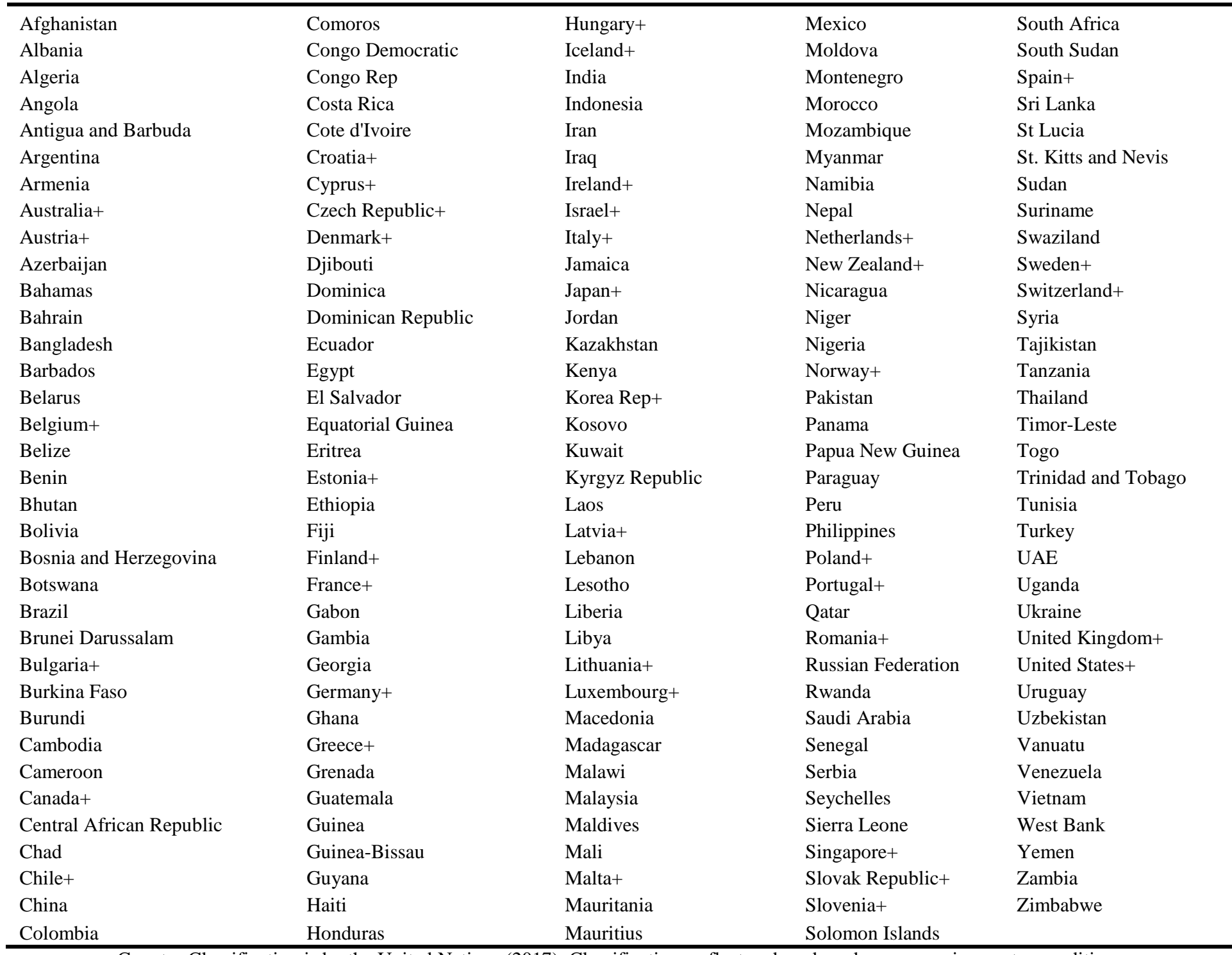

Country Classification is by the United Nations (2017). Classifications reflect and are based on economic country conditions such as per capita gross national income, human assets, etc. 
Table1B

Sample Countries

This table presents the sub-sample of countries employed for our analysis on the impact of terrorism on business failure in 39 fragile countries over the period 2009-2015. * is for SSA countries, ** is for South Asian countries, *** is for MENA countries.

\begin{tabular}{lll}
\hline Afghanistan** & Indonesia & Philippines \\
Algeria*** & Iran*** & Rwanda* \\
Bangladesh** & Iraq*** & Senegal* \\
Burundi* & Kenya* & Sri Lanka** \\
Cameroon* & Lebanon*** & South Sudan* \\
Central African Republic* & Libya*** & Sudan* \\
Chad* & Mali* & Syria*** \\
Colombia & Mozambique* & Thailand \\
Congo Democratic* & Myanmar & Tunisia*** \\
Cote d'Ivoire* & Nepal** & Turkey*** \\
Egypt*** & Niger* & Uganda* \\
Ethiopia* & Nigeria* & West Bank*** \\
India** & Pakistan** & Yemen*** \\
\hline
\end{tabular}

Source for Fragile Countries Ranking is the Fragile States Index (FSI, 2017). The rankings are based on a conflict assessment framework that builds from indicators that capture those of cohesion, political, economic and social factors

Table 2 Variables definitions

List of Variables

Definitions

Dependent variables

Business Failure

This is a country-level measure of the percentage of businesses that are likely to fail. The measure is an adaptation of the World Bank Doing Business' resolving insolvency index which measures the likelihood of businesses in a particular country of surviving.

Independent variable

Terrorism

This captures the number of terrorist incidents in a given year. Terrorism is defined as the planned use of threat of extra-normal violence by subnational groups to obtain a political, religious, or ideological objective through threats to a large audience, usually not directly involved with the decision making (GTD 2017; Ismail \& Amjad 2014).

\section{Control variables}

GDP

Savings (\$US, Log)

Credit to Private Investors (\$US, Log)

Inflation

Lending Rate (\%)
Measures the sum of gross value added by all resident producers in an economy (WDI 2017).

Measures the difference between GDP and total consumption (WDI 2017).

This refers to financial resources provided to the private sector by financial corporations, such as through loans, purchases of non-equity securities, and trade credits (WDI 2017).

Annual \% change in the cost of consumer goods and services (WDI 2013).

This refers to the bank rate that usually meets the short- and medium-term financing needs of the private sector (WDI 2017). 
Table 3A

Descriptive Statistics (Global Sample)

This table presents the summary statistics of the variables employed in the analysis. GDP, Savings, and Credit to Private Investors are in US\$ billion.

\begin{tabular}{|c|c|c|c|c|c|c|c|c|}
\hline & & & All Countries & & & & Developed & Developing \\
\hline & Mean & 25th percentile & 75th percentile & Std. Dev. & Min. & Max. & Mean & Mean \\
\hline \multicolumn{9}{|l|}{ Dependent Variable } \\
\hline \multicolumn{9}{|l|}{ Independent Variable } \\
\hline Terrorism & 53.024 & 0.000 & 5.000 & 248.636 & 0.000 & 3925.000 & 7.975 & 70.563 \\
\hline \multicolumn{9}{|l|}{ Control Variables } \\
\hline GDP & 410.000 & 9.200 & 219.000 & 1520.000 & 0.598 & 6200.000 & 1130.000 & 191.000 \\
\hline Savings & 119.000 & -1.970 & 4260.000 & 444.000 & -15.700 & 5350.000 & 238.000 & 84.000 \\
\hline Inflation & 4.995 & -4.480 & 53.229 & 7.081 & -8.283 & 109.681 & 1.629 & 5.876 \\
\hline Lending Rate (\%) & 11.306 & 0.500 & 60.000 & 7.361 & 0.500 & 65.418 & 6.335 & 12.489 \\
\hline Credit to Private Investors & 514.000 & 0.079 & 28900.000 & 2680.000 & 0.036 & 34100.000 & 1700.000 & 179.000 \\
\hline
\end{tabular}


Table 3B

Descriptive Statistics (Fragile Countries)

This table presents the summary statistics of the variables employed in the analysis for the fragile countries. GDP, Savings, and Credit to Private Investors are in US\$ billion.

\begin{tabular}{|c|c|c|c|c|c|c|c|c|c|}
\hline & & & Total & & & & SSA & South Asia & MENA \\
\hline & Mean & 25th percentile & 75th percentile & Std. Dev. & Min. & Max. & Mean & Mean & Mean \\
\hline \multicolumn{10}{|l|}{ Dependent Variable } \\
\hline Business Failure & 66.539 & 57.650 & 74.420 & 14.612 & 22.320 & 96.610 & 71.141 & 64.313 & 65.886 \\
\hline \multicolumn{10}{|l|}{ Independent Variable } \\
\hline Terrorism & 217.578 & 0.000 & 2214.000 & 488.108 & 0.000 & 3925.000 & 43.190 & 571.500 & 311.971 \\
\hline \multicolumn{10}{|l|}{ Control Variables } \\
\hline GDP & 180.000 & 15.300 & 212.000 & 335.000 & 1.700 & 1860.000 & 45.570 & 377.660 & 197.017 \\
\hline Savings & 49.500 & -3.970 & 599.000 & 111.000 & -5.260 & 636.000 & 8.540 & 108.000 & 52.600 \\
\hline Inflation & 7.382 & -2.248 & 39.266 & 8.226 & -8.283 & 50.151 & 8.055 & 7.178 & 8.441 \\
\hline Lending Rate (\%) & 12.751 & 5.679 & 28.447 & 7.117 & 5.526 & 65.418 & 15.511 & 11.790 & 11.315 \\
\hline Credit to Private Investors & 86.100 & 0.178 & 948.000 & 191.000 & 0.077 & 1090.000 & 7.190 & 177.000 & 102.000 \\
\hline
\end{tabular}

Sources: GTD (2017); WDI (2017). Summary statistics for SSA, South Asia and MENA countries are those of highly terror-prone and failed states

Table 4A

Correlation Matrix (Global Sample)

\begin{tabular}{|c|c|c|c|c|c|c|c|c|}
\hline & & 1 & 2 & 3 & 4 & 5 & 6 & 7 \\
\hline 1 & Business Failure & 1.000 & & & & & & \\
\hline 2 & Terrorism & 0.074 & 1.000 & & & & & \\
\hline 3 & GDP & 0.248 & 0.014 & 1.000 & & & & \\
\hline 4 & Savings & -0.463 & 0.150 & -0.066 & 1.000 & & & \\
\hline 5 & Inflation & 0.306 & 0.042 & -0.073 & -0.077 & 1.000 & & \\
\hline 6 & Lending Rate (\%) & 0.461 & 0.032 & 0.064 & -0.270 & 0.338 & 1.000 & \\
\hline 7 & Credit to Private Investors & -0.654 & -0.116 & -0.216 & 0.446 & -0.309 & -0.449 & 1.000 \\
\hline
\end{tabular}

Table 4B

Correlation Matrix (Fragile Countries)

\begin{tabular}{|c|c|c|c|c|c|c|c|c|}
\hline & & 1 & 2 & 3 & 4 & 5 & 6 & 7 \\
\hline 1 & Business Failure & 1.000 & & & & & & \\
\hline 2 & Terrorism & -0.039 & 1.000 & & & & & \\
\hline 3 & GDP & 0.037 & -0.020 & 1.000 & & & & \\
\hline 4 & Savings & -0.329 & 0.356 & 0.011 & 1.000 & & & \\
\hline 5 & Inflation & 0.140 & -0.070 & -0.269 & 0.031 & 1.000 & & \\
\hline 6 & Lending Rate (\%) & 0.220 & -0.009 & 0.019 & -0.231 & 0.196 & 1.000 & \\
\hline 7 & Credit to Private Investors & -0.440 & -0.090 & -0.014 & 0.350 & -0.133 & -0.341 & 1.000 \\
\hline
\end{tabular}


Table 5

Fixed-effects (country and year effects) Estimations.

This table presents the regression results of the estimations for the entire sample and sub-samples. $t$ statistics are in parentheses. *Significance at the $10 \%$ Level; ${ }^{* *}$ Significance at the $5 \%$ Level; ${ }^{* * * S i g n i f i c a n c e ~ a t ~ t h e ~} 1 \%$ Level.

\begin{tabular}{|c|c|c|c|c|}
\hline $\begin{array}{l}\text { Dependent Variable } \\
\text { Business Failure }\end{array}$ & $\begin{array}{l}\text { Fixed-effects } \\
\text { Model } 1 \\
\text { All countries } \\
\end{array}$ & $\begin{array}{c}\text { Fixed-effects } \\
\text { Model } 2 \\
\text { Developed countries } \\
\end{array}$ & $\begin{array}{c}\text { Fixed-effects } \\
\text { Model } 3 \\
\text { Developing countries } \\
\end{array}$ & $\begin{array}{c}\text { Fixed-effects } \\
\text { Model } 4 \\
\text { Fragile countries }\end{array}$ \\
\hline \multicolumn{5}{|l|}{ Independent Variables } \\
\hline Terrorism & $\begin{array}{c}0.014 * * * \\
(6.920)\end{array}$ & $\begin{array}{c}0.054 \\
(1.100)\end{array}$ & $\begin{array}{c}0.006 * * \\
(2.790)\end{array}$ & $\begin{array}{c}0.010 * * * \\
(5.020)\end{array}$ \\
\hline \multicolumn{5}{|l|}{ Control Variables } \\
\hline GDP & $\begin{array}{c}-2.590^{* * *} \\
(-7.260)\end{array}$ & $\begin{array}{c}-4.944 * * * \\
(-25.760)\end{array}$ & $\begin{array}{c}-0.603 \\
(-1.710)\end{array}$ & $\begin{array}{c}-4.033^{* * *} \\
(-6.880)\end{array}$ \\
\hline Savings (\$US, Log) & $\begin{array}{c}0.168 * * * \\
(6.760)\end{array}$ & $\begin{array}{c}0.479 * * * \\
(3.360)\end{array}$ & $\begin{array}{c}0.068^{* *} \\
(3.070)\end{array}$ & $\begin{array}{c}0.221^{* *} \\
(3.300)\end{array}$ \\
\hline Inflation & $\begin{array}{c}0.101 \\
(1.580)\end{array}$ & $\begin{array}{c}-0.613 \\
(-1.670)\end{array}$ & $\begin{array}{c}0.130^{* *} \\
(3.360)\end{array}$ & $\begin{array}{c}0.383 * * \\
(2.980)\end{array}$ \\
\hline Lending Rate (\%) & $\begin{array}{c}0.755^{* * *} \\
(9.400)\end{array}$ & $\begin{array}{c}0.441 \\
(0.950)\end{array}$ & $\begin{array}{c}0.456 \\
(8.630)\end{array}$ & $\begin{array}{c}-0.225 \\
(-0.850)\end{array}$ \\
\hline Credit to Private Investors (\$US, Log) & $\begin{array}{c}-0.177 * * * \\
(-6.660)\end{array}$ & $\begin{array}{l}-0.085^{* *} \\
(-2.550)\end{array}$ & $\begin{array}{l}-0.095 * * * \\
(-17.427)\end{array}$ & $\begin{array}{c}-0.133^{* * *} \\
(-4.390)\end{array}$ \\
\hline Cons. & $\begin{array}{c}6.456 \\
(0.980)\end{array}$ & $\begin{array}{c}122.000^{* *} \\
(3.210)\end{array}$ & $\begin{array}{c}-39.130 * * * \\
(-4.370)\end{array}$ & $\begin{array}{l}24.120 \\
(1.520)\end{array}$ \\
\hline R Squared & 0.4537 & 0.2701 & 0.6350 & 0.7738 \\
\hline Number of Observation & 762 & 225 & 537 & 146 \\
\hline
\end{tabular}

Note: Number of observations vary due to missing data of some of the dependent and control variables. Values in table have been approximated to 3 decimal places.

\section{Table 6 Estimations of the Marginal Effects (Fragile Countries)}

This table presents the regression results of the marginal effects of the fragile countries. $t$ statistics are in parentheses. *Significance at the $10 \%$ Level; **Significance at the $5 \%$ Level; $* * *$ Significance at the $1 \%$ Level.

\begin{tabular}{|c|c|c|c|}
\hline Dependent Variable & Fixed-effects & Fixed-effects & Fixed-effects \\
\hline Business Failure & $\begin{array}{c}\text { SSA } \\
\text { Countries } \\
\text { Marginal Effects } \\
\text { Model } 7\end{array}$ & $\begin{array}{c}\text { South Asian } \\
\text { Countries } \\
\text { Marginal Effects } \\
\text { Model } 8 \\
\end{array}$ & $\begin{array}{c}\text { MENA } \\
\text { Countries } \\
\text { Marginal Effects } \\
\text { Model 9 }\end{array}$ \\
\hline \multicolumn{4}{|l|}{ Independent Variable } \\
\hline Terrorism & $\begin{array}{c}0.007 * * * \\
(5.230)\end{array}$ & $\begin{array}{l}0.010^{* *} \\
(2.500)\end{array}$ & $\begin{array}{c}-0.002 \\
(-0.290)\end{array}$ \\
\hline
\end{tabular}

Values in table have been approximated to 3 decimal places. 